\title{
Pelatihan Pemanfaatan Media Sosial untuk Promosi Wisata Puncak Pinus Desa Dulamayo Selatan
}

\author{
Windra Irawan, Andi Suci Anita, Yasir M. Pidu, Raflen Aril Gerungan, Nur Asiah \\ Universitas Terbuka
}

windra@ecampus.ut.ac.id, andianita@ecampus.ut.ac.id, yasirm@ecampus.ut.ac.id, raflenaril@ecampus.ut.ac.id,nur@ecampus.ut.ac.id

\begin{abstract}
Abstrak
Desa Dulamayo Selatan, Kecamatan Telaga, Kabupaten Gorontalo memiliki potensi wisata yang disebut Puncak Hutan Pinus Dulamayo. Saat ini masyarakat dan pengelola belum mampu memperkenalkan dengan baik ke masyarakat luas. Padahal jika dipromosikan dengan baik, wisata Puncak Pinus Dulamayo secara langsung memberikan banyak peluang usaha untuk meningkatkan kesejahteraan masyarakat sekitar. Pengabdian kepada masyarakat ini, memberikan pelatihan pemanfaatan media sosial untuk promosi Puncak Dulamayo. Media sosial seperti youtube, facebook, instagram, dan tiktok merupakan media yang efektif dan efisien dalam mempromosikan sesuatu. Pelatihan bertujuan memberikan pengetahuan dan keterampilan pengelola wisata, karang taruna, pengurus bumdes dan masyarakat dalam menggunakan media sosial. Metode pelatihan adalah presentasi ceramah, diskusi, dan praktek langsung. Materi presentasi yang diberikan meliputi perkenalan berbagai media sosial, perbedaan dan keunggulan masing-masing media sosial, serta materi internet sehat dan bijak dalam bermedia sosial. Metode diskusi dan praktek diberikan untuk memastikan peserta mampu mendaftar akun, mengenal menu dan fitur media sosial, hingga membuat konten untuk tujuan promosi wisata.
\end{abstract}

Kata Kunci : pelatihan, media sosial, promosi wisata

\section{PENDAHULUAN}

Sebagai bagian dari Pulau Sulawesi, Provinsi Gorontalo memiliki luas $11.257 \mathrm{~km}^{2}$, terdiri dari 5 Kabupaten dan 1 Kotamadya. Pada bagian timur berbatasan dengan Provinsi Sulawesi Utara, bagian Barat berbatasan dengan Provinsi Sulawesi Tengah, bagian utara merupakan daerah pantai laut sulawesi dan bagian selatan merupakan laut teluk tomini.

Karakter geografis yang diapit dua laut di bagian utara dan selatan membuat banyak tujuan dan potensi wisata Gorontalo adalah pantai, pulau dan lautnya. Beberapa destinasi wisata terkenal yang telah mendunia diantaranya Pulau Cinta di Kabupaten Boalemo, Tanjung Oile dan Pulau Saronde dari Kabupaten Gorontalo Utara, spot menyelam (diving) di Desa Olele Kabupaten Bone Bolango.

Selain pantai dan laut, Gorontalo memiliki banyak tujuan wisata yang layak dikunjungi seperti, Danau Limboto dan Menara Keagungan di Kabupaten Gorontalo, Benteng Otanaha dan Rumah 
Adat Dulohupa di Kota Gorontalo dan masih banyak lagi wisata budaya dan wisata religius yang tersebar di beberapa daerah.

Namun demikian, destinasi wisata dengan konsep alam pegunungan tidak banyak dikenal di Gorontalo. Padahal Gorontalo memiliki bentangan alam pegunungan yang indah, layak untuk menjadi destinasi wisata, baik skala lokal maupun nasional.

Salah satu potensi wisata berupa alam pegunungan di Gorontalo adalah Puncak Pinus Desa Dulamayo Selatan. Desa Dulamayo Selatan, berada di wilayah Kecamatan Telaga, Kabupaten Gorontalo, Puncak Pinus Dulamayo mimiliki ketinggian 827 meter di atas permukaan laut. Jarak dari ibu kota provinsi sekitar $30 \mathrm{~km}$ dan bisa ditempuh 45 menit perjalanan dengan kendaraan bermotor.

Namun demikian keindahan alam di Puncak Dulamayo belum maksimal dipromosikan oleh pengelola atau masyarakat, aparat desa atau BUMDes, karang taruna pemuda setempat. Sehingga potensi wisata yang dimiliki belum dikenal dengan baik dan tidak memberikan dampak ekonomi kepada masyarakat sekitar.

Oleh karena itu, Universitas Terbuka Gorontalo melakukan pengabdian kepada masyarakat yaitu Pelatihan Pemberdayaan Bumdes di Desa Dulamayo Selatan. Salah satu pelatihan yang diberikan adalah digital marketing. Aplikasi dari pelatihan digital marketing yaitu materi pemanfaatan media sosial sebagai promosi wisata Puncak Pinus Dulamayo.

Pelatihan ini diberikan yaitu mempunya tujuan untuk memperkenalkan dan mengaplikasikan media sosial yang populer dan banyak dipergunakan masyarakat, seperti facebook, youtube, instagram dan tiktok. Media sosial terbut adalah platform media yang dianggap efektif dan efisien dalam melakukan promosi dan memperkenalkan potensi wisata yang dimiliki Desa Dulamayo.

\section{TINJAUAN PUSTAKA}

\section{Wisata Berkelanjutan dan Penerapan Teknologi}

United Nations Environment Programme on Tourism mendefinisikan bahwa wisata berkelanjutan (sustainable tourism) adalah pengelolaan potensi wisata yang mendukung kebutuhan wisata dengan tetap mempertimbangkan, melindungi, dan mempertinggi potensi asset untuk masa yang akan datang.

Dengan demikian, pembangunan harus memperhitungkan potensi masa depan semua sektor, termasuk faktor ekonomi, sosial dan budaya, budaya yang terintegrasi, proses ekologi utama, keanekaragaman hayati dan penyangga kehidupan.

Dalam Piagam Pariwisata Berkelanjutan (1995) disebutkan bahwa "Pembangunan pariwisata harus didasarkan pada kriteria keberlanjutan yang artinya bahwa pembangunan dapat didukung secara ekologis dalam jangka panjang sekaligus layak secara ekonomi, adil secara etika dan sosial terhadap masyarakat."

Dengan demikian secara ringkas, konsep pengembangan pariwisata secara berkelanjutan tersebut pada intinya menekankan pada 4 (empat) prinsip, sebagai berikut :

a. Berwawasan lingkungan (enviromentaly sustainable)

b. Diterima secara sosial dan budaya (socially and culturally acceptable)

c. Layak secara ekonomi (economically viable)

d. Penerapan teknologi layak guna (technologically appropriate)

Kesesuaian prinsip secara teknologi, menekankan bahwa proses pengembangan wisata dapat dilakukan secara efektif dan efisien dengan menggunakan sumber daya lokal yang dapat dengan mudah diadopsi masyarakat

Teknologi Informasi dan Komunikasi 80 
lokal untuk selanjutnya menjadi target proses manajemen jangka panjang. (Prakoso, A. A, 2015)

Kawasan Dumalayo memiliki luas kurang lebih 71.000 ha dan termasuk dalam kawasan hutan lindung. Menurut UU Cipta Kerja, kawasan dural mayo termasuk dalam kawasan hutan produksi yang kegiatan ekonominya dibatasi sesuai dengan daya dukung lingkungan. Menurut data Dinas Kehutanan Gorontalo dan Kementerian Lingkungan Hidup, di wilayah tersebut terdapat blok daerah khusus yang diperuntukkan bagi pendidikan Universitas Gorontalo. (bappeda.gorontaloprov.go.id)

\section{Promosi Wisata}

Dalam penjualan jasa dan produk selalu memerlukan metode dan strategi untuk menawarkan produk dan layanannya. Salah satu strategi yang sering digunakan dalam menawarkan produk atau jasa yaitu dengan promosi. (Anggraini, 2020)

Promosi merupakan upaya sosialisasi kepada masyarakat luas yang dapat dilakukan secara langsung maupun melalui media. Sebelum adanya media sosial, promosi bermedia selalu membutuhkan biaya yang besar. Tetapi setelah era digital sekaran, promosi menggunakan media sosial dianggap lebih efektif dan efisien. melalui Instagram, YouTube, Facebook, Tweeter dan lain-lain. (Barokah et al., 2021)

Hal utama dalam promosi adalah membuat pesan persuasif yang efektif menarik perhatian orang lain atau konsumen (Puspitarini \& Nuraeni, 2019). Sehingga setiap usaha baik individu atau perorangan dapat menggunakan semua sumber daya, fasilitas atau fitur-fitur yang ada dan disediakan untuk mencapai tujuannya.

\section{Media Sosial}

Media Sosial merupakan sarana komunikasi dan keterhubungan sosial dengan menggunakan jaringan internet. Pengguna media sosial melakukan komunikasi, interaksi, berkirim pesan, dan saling berbagi atau sharing, dan membangun jaringan sosial dengan orang lain. (www.romelteamedia.com)

Pertumbuhan peran media sosial dalam pariwisata semakin menjadi topik penelitian yang muncul. Media sosial memainkan peran penting dalam banyak aspek pariwisata, terutama dalam pencarian informasi dan perilaku pengambilan keputusan, promosi pariwisata dan dalam berfokus pada praktik terbaik untuk berinteraksi dengan konsumen. Memanfaatkan media sosial untuk memasarkan produk pariwisata telah terbukti menjadi strategi yang sangat baik. (Zeng \& Gerritsen, 2014)

Berdasarkan data dari wearesosial.com (2020), dari total penduduk Indonesia sebanyak 274,9 juta, 170 juta merupakan pengguna aktif media sosial. Artinya pada Januari 2021 jumlah pengguna media sosial Indonesia akan mencapai $61,8 \%$ dari total populasi. Angka ini juga meningkat menjadi 10 juta, meningkat sekitar 6,3\% dibandingkan tahun lalu.

Dari data tersebut juga disebutkan bahwa pengguna Youtube di Indonesia sebanyak $88 \%$ dari jumlah populasi, Whatsapp $84 \%$, Facebook $82 \%$, dan pengguna Instagram sebanyak $79 \%$, twitter 56\%, dan pengguna Tiktok sebanyak $25 \%$ dari total populasi Indonesia. (https://wearesocial.com)

\section{METODOLOGI}

Pelatihan terdiri dari beberapa metode yaitu ceramah, diskusi, dan praktek kerja kelompok. Dalam praktek kerja kelompok diberikan pendampingan oleh narasumber dan fasilitator, sehingga peserta langsung praktek. Masing-masing metode pelatihan diberikan waktu yang cukup penguasaan dan pencapaian tujuan pelatihan.

Metode ceramah digunakan untuk memberikan informasi dan pengetahuan

Teknologi Informasi dan Komunikasi 81 
memanfaatkan media sosial untuk lebih memperkenalkan objek wisata yang ada. Indikator keberhasilan dari metode ini adalah peserta pelatihan mampu menjelaskan:

1. Media-media sosial yang bisa digunakan keperluan promosi wisata, seperti facebook, intagram, dan tiktok;

2. Kelebihan dan kekurangan dari masingmasing media sosial;

3. Aplikasi-aplikasi gratis yang dapat dipergunakan untuk mengolah teks, gambar, suara, dan video.

Kemudian, setelah materi diberikan secara classical, dilanjutkan dengan metode diskusi. Metode ini digunakan untuk mengangkat permasalahan dan kesulitan saat membuat konten media sosial sebagai alat promosi wisata. Masalah tersebut kemudian dipecahkan bersama dengan panduan dan arahan narasumber dan fasilitator. Indikator keberhsailan diskusi adalah ketika peserta mampu memecahkan masalah atau membuat rekomendasi terhadap permasalahan yang dihadapi dalam menggunakan media sosial sebagai sarana promosi.

Selanjutnya adalah metode praktek kerja kelompok. Metode ini digunakan untuk mengaplikasikan secara langsung dengan membuat produk berdasarkan informasi dan pengetahuan yang diberikan saat metode ceramah dan diskusi. Indikator keberhasilan metode ini adalah ketika peserta mampu membuat dan menghasilkan produk untuk diunggah di media sosial.

Selain itu dalam praktek, peserta diharapkan mampu memanfaatkan penggunaan teks, suara, gambar dan video untuk pembuatan konten promosi wisata. Dalam praktek difokuskan ke plaftform yang semua peserta mempunyai akun, sehingga bisa dipraktekkan secara bersama-sama.

Pelatihan ini diselenggarakan satu rangkaian kegiatan dengan Pelatihan
Pemberdayaan Bumdes Desa Dulamayo Selatan.

\section{HASIL DAN PEMBAHASAN}

Kegiatan pengabdian kepada masyarakat ini masuk dalam rangkaian pengabdian kepada masyarakat Universitas Terbuka - Gorontalo tahun 2021. Pelatihan pemanfaatan media sosial sebagai promosi wisata Puncak Pinus diberikan dalam kategori kelompok digital marketing.

Peserta yang hadir adalah Aparat Desa, unsur Badan Permusyawaratan Desa (BPD), Lembaga Pemberdayaan Masyarakat (LPM), Bumdes dan kelompok milenial di Desa Dulamayo Selatan. Dengan kehadiran unsur aparatur desa dan unsur pendukungnya merupakan diharapkan dapat menjadi inisiator dan penggerak bagi peningkatan kunjungan wisata di Puncak Pinus Dulamayo.

Selain dari Desa Dulamayo Selatan, turut diundang juga dari desa terdekat yang memiliki potensi wisata yang sama, namun belum dimanfaatkan.

Pemberiaan materi tentang media sosial diawali dengan identifikasi berupa identifikasi kepemilikan media sosial, kemampuan unggah atau posting, dan identifikasi kepemilikan sumber daya pendukung, berikut hasil identifikasi:

\section{Identifikasi kepemilikan akun media}

Identifikasi kepemilikan akun sosial secara pribadi atau kelompok, terdiri dari memiliki akun dan aktif, serta aktif tapi tidak memiliki akun media sosial.

Dalam proses identifikasi ini diketahui bahwa semua peserta telah memiliki minimal satu akun media sosial, yaitu facebook, beberapa memiliki akun instagram dan tidak ada yang memiliki akun tiktok.

Berikut tabel identifikasi kepemilikan media sosial dari peserta pelatihan : 
Tabel 1. Identifikasi akun media sosial

\begin{tabular}{lcc}
\hline Medsos & $\begin{array}{c}\text { Memiliki } \\
\text { Akun }\end{array}$ & $\begin{array}{c}\text { Aktif } \\
\text { Tanpa } \\
\text { Akun }\end{array}$ \\
\hline Facebook & Semua & - \\
\hline Instagram & Sedikit & Sedikit \\
\hline Youtube & Sedikit & Banyak \\
\hline Tiktok & Tidak ada & Sedikit \\
\hline
\end{tabular}

Facebook menjadi media paling sering digunakan oleh semua peserta karena keberadaanya sudah lebih lama dan peserta menganggap lebih mudah selain itu karena teman, keluarga, dan hampir semua orang aktif dan memiliki facebook. Penggunaan facebook lebih sering untuk share teks dan gambar, sesekali menggunakan live yang kemudian menjadi video.

Sedangkan untuk kelompok milineal, selain facebook mereka juga aktif di instagram. Namun tidak seaktif seperti facebook. Sedangkan tiktok, mereka menganggap bahwa tiktok lebih sering ditonton daripada digunakan sebagai media sosial.

Dari identifikasi penggunaan media sosial, selanjutnya narasumber memberikan gambaran bagaimana keunggulan dan kekurangan masing-masing media sosial, yaitu facebook, instagram, dan tiktok.

\section{Identifikasi kemampuan memanfaatkan media di media sosial.}

Setelah identifikasi keaktifan media sosial dan dijelaskan perbedaan plaftform masing-masing media sosial. Peserta didentifikasi kemampuan mengunggah (pors) media di media sosial, meliputi penggunaan text, gambar dan video, atau gabungan ketiganya.

Rata-rata peserta telah mampu membuat posting dalam facebook dengan berbagai bentuak unggahan atau posting, baik text sederhana, postingan gambar, merekam dan live video. Peserta hanya tidak pernah menggunakan video yang telah diedit dengan baik.

\section{Identifikasi hardware dan jaringan internet peserta.}

Sumber daya yang diidentifikasi adalah perangkat keras dan jaringan internet yang digunakan. Dalam identifikasi ini semua peserta dalam akses internet menggunakan telepon genggam (smartphone) android. Beberapa juga menggunakan laptop tapi penggunaannya hanya terbatas untuk pekerjaan, jarang digunakan untuk akses internet atau media sosial.

Sedangkan dalam menggunakan internet, peserta lebih banyak menggunakan jaringan WIFI di kantor desa masing-masing. Sedangkan di tempat domisili masing-masing belum terjangkau oleh jaringan seluler.

Keterbatasan jaringan hanya di WIFI kantor menjadikan peserta memiliki waktu yang terbatas dalam memanfaatkan internet yaitu pada jam kerja atau saat pergi ke daerah yang tersedia akses.

Dari hasil identifikasi peserta dalam penggunaan, kemampuan dan akses media sosial. Dari hasil identifikasi diberikan penekanan bahwa media sosial dititik beratkan ke facebook, dipraktekkan cara membuat akun intagram dan youtube serta diperkenalkan media sosial tiktok yang sedang populer saat ini.

Pelatihan dilanjutkan dengan memberikan materi mengenai karakteristik media sosial, termasuk facebook, youtube, intagram, dan tiktok;

1) Facebook

Merupakan media sosial paling populer karena jumlah penggunanya yang paling banyak. Platform ini berbasis pertemanan, keluarga, saudara, rekan kerja, dan sebagainya. Karakter Facebook yang dmikian maka melahirkan halaman-halaman komunitas. 


\section{2) Instagram}

Instagram adalah platform dengan konten gambar atau foto yang mengutamakan keindahan. Mayoritas penggunanya instagram adalah millennial. Pengguna instagram adalah remaja rentang usia 15-22 tahun. Hal ini wajar karena dengan mengirim foto atau video ke dalam media sosial untuk menjalin relasi sosial dengan orang lain dapat terpenuhi. (Setiasih \& Puspitasari, 2017)

Karakter dari instagram yang mengangkat keindahan pada postingan penggunnya, membuat Instagram lebih efektif untuk menjadi media promosi keindahan wisata.

3) Youtube

YouTube adalah platform penampil video yang terbesar. Konten YouTube secara fleksibel bisa dishare dihampir seluruh platform media sosial.

Konten yang dibuat harus dapat menarik penonton dan unik sehingga memunculkan kekhasan yang tidak dimiliki pengguna lain. Saat ini Youtube dianggap salah satu aplikasi media yang dapat memenuhi kebutuhan informasi di era modern saat ini. Posisinya dapat dibandingkan dengan televisi tradisional namun dengan muatan yang sangat beragam tergantung preferensi pengguna atau penonton. (Fauzan, 2019)

4) Tiktok

Tiktok adalah platform video singkat. Video memiliki durasi terbatas, yaitu hanya 15 detik atau 60 detik. Justru dengan durasi yang singkat ini menjadi daya tarik tiktok. Dengan waktu yang pendek pengguna dituntut untuk menyampaikan pesannya dengan menarik dan berbeda dari konten laiinya.

Dengan durasi yang singkat pengguna harus mampu menuangkanya dalam kreatifitas yang unik. Selain itu juga tiktok banyak memberikan fitur-fitur menarik yang dapat menghiasa konten pnegguna tanpa aplikasi tambahan dan gratis.
Ketenaran Tiktok semakin tinggi setelah munculnya pandemi Covid-19. Pada tahun 2020 tiktok sudah diunguh pengguna 63,3 juta kali. Indonesia menyumbang $11 \%$ sebagai negara yang paling banyak mengunduh aplikasi Tiktok. (Dewa \& Safitri, 2021)

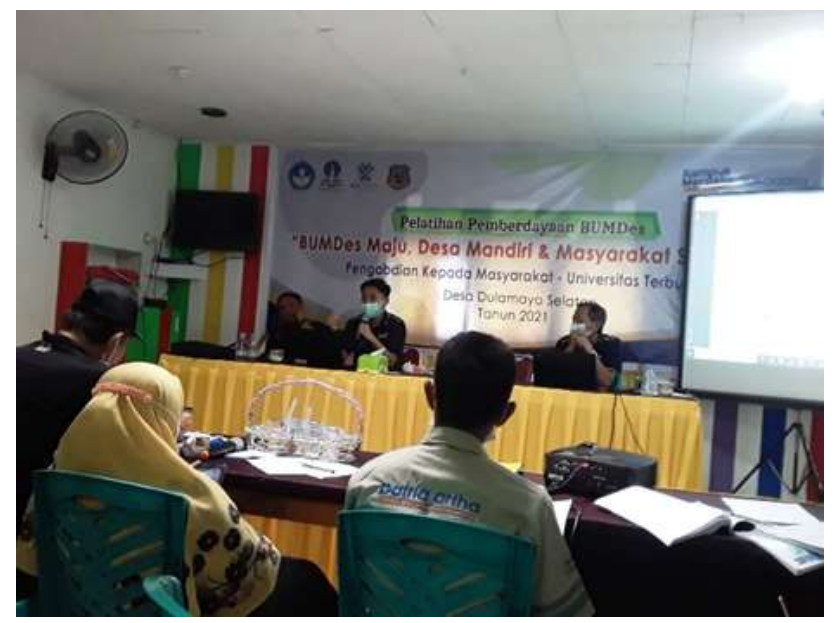

Gambar 1. Narasumber menyampaikan materi tentang media sosial

Sebagai pendukung materi diperkenalkan juga aplikasi yang dapat membantu peserta dalam memperkaya dan membuat postingan di media sosial agar lebih menarik, yaitu aplikasi

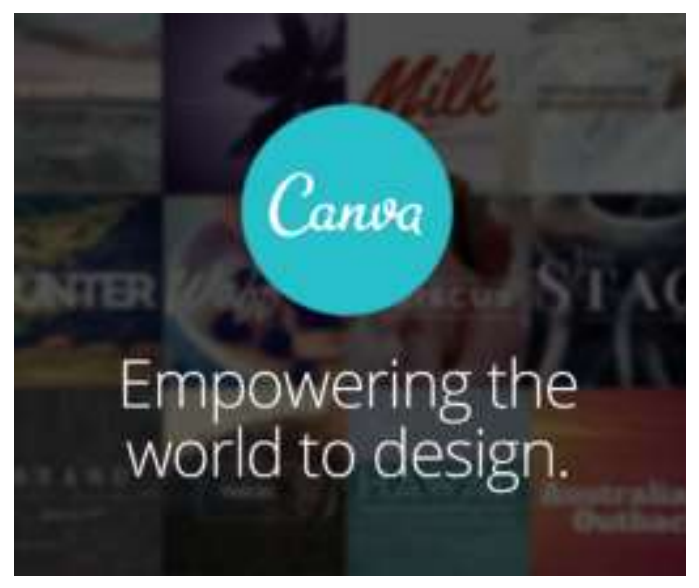

Canva.

Gambar 2. Logo aplikasi Canva 
Canva diperkenalkan karena, memiliki tampilan antar muka sederhana mudah digunakan, bahkan oleh pengguna yang belum pernah menggunakan software desain grafis sebelumnya. Selain itu Canva mempunyai banyak template desain gratis untuk berbagai kebutuhan desain.

Karena berbasis cloud, pengguna juga tidak diwajibkan untuk instalasi di komputer atau di smarthphone. Karena itu, kekurangan Canva adalah harus selalu terhubung dengan jaringan internet.

Setelah pemaparan materi, kemudian peserta diberikan bimbingan langsung dengan menggunakan aplikasi Canva untuk berkreasi sebagai bahan untuk posting dimedia sosial.

Karena jaringan internet yang digunakan tidak mampu memenuhi kebutuhan semua peserta, baik dari segi kecepatan dan besaran kapasitas internet. Sehingga praktek pelatihan dilakukan secara berkelompk peserta dengan jaringan internet tidak baik, bisa berbagi dengan peserta lainnya.

Adanya kendala jaringan internet sehingga praktek pelatihan dibatasi dengan membuat desain untuk promosi Wisata Puncak Pinus Dumalayo. Selanjutnya diunggah dalam media sosial masing-masing peserta atau perwakilan kelompok.

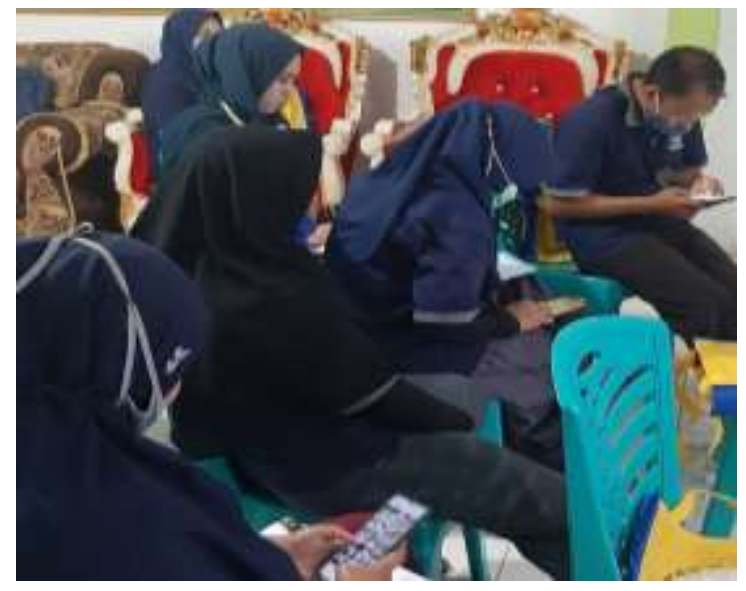

Gambar 3. Peserta menggunakan Canva
Selama pelatihan, peserta juga diarahkan untuk sefektif dan seefisien mungkin memanfaatkan kelebihan masing-masing dari media sosial. Seperti penggunaan tag dan hastag (\#), penggunaan mention (@) dan link serta fitur-fitur lain yang dianggap mampu meningkatkan ketertarikan pengguna media sosial.

Berikut contoh produk sederhana yang telah dibuat oleh perserta pelatihan.

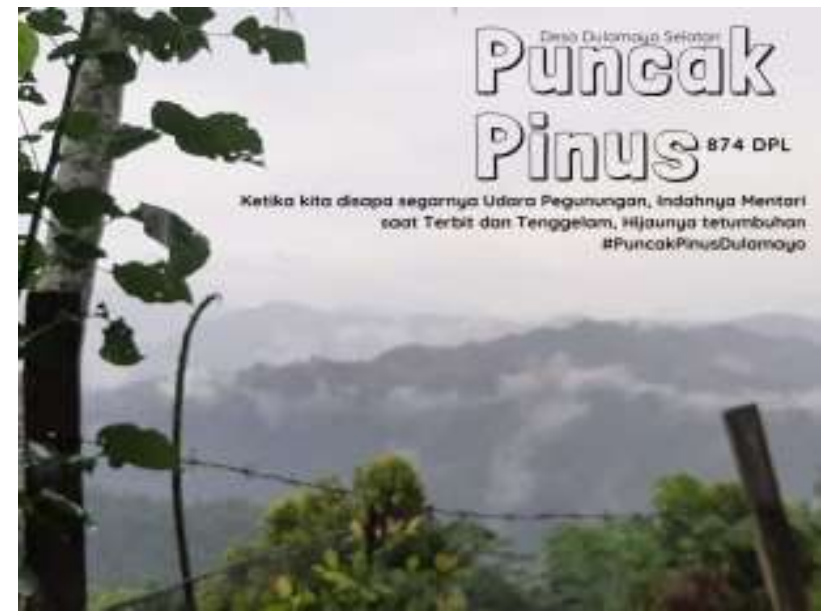

Gambar 4. Contoh gambar promosi Puncak Pinus Dulamayo

Meskipun gambar yang dihasilkan masih sangat sederhana, namun peserta diharapkan mampu meningkatkan keterampilannya dengan penggunaan yang lebih sering dan memperkaya dari sumber lain.

\section{KESIMPULAN}

Pelatihan pemanfaatan media sosial sebagai saran promosi wisata yang telah dilakukan mampu memberikan pengetahuan dan keterampilan dasar kepada peserta tentang pemanfaatan media sosial sebagai dalam menampilkan, memperkenalkan dan mempromosikan secara efektif dan efisien wisata Puncak Pinus Dulmayo. Indikasinya adalah beberapa peserta dianggap telah mampu membuat media promosi dan upload hasil kerja ke media sosial. 
Namun demikian, disarankan bahwa kemampuan peserta secara individu akan lebih baik jika manajemen secara kelompok baik oleh desa ataupun oleh bumdes. Sehingga promosi yang dilakukan tidak hanya secara insidental tapi secara berkesinambungan terus dilakukan.

Dalam pelatihan ini ada 4 media sosial yang diperkenalkan, yaitu facebook, instagram, youtube, dna tiktok. Namun tidak semuanya bisa secara efektif dipraktekan secara terbimbing. Namun peserta telah diberikan dasar khususnya aplikasi Canva yang bisa mencakup editing desain grafis baik text, gambar, maupun video.

Terbatasnya waktu dan kecepatan jaringan dalam pelatihan sedikit menghambat pelaksanaan dan praktek pelatihan, namun demikian, antusias peserta untuk lebih memperkenalkan wisata Puncak Pinus Dulamayo Selatan kepada masyarakat, diharapkan membuahkan hasil dengan peningkatan keinginan wisatawan untuk berkunjung, dan menjadi destinasi wisata berkelanjutan, serta menjadi sumber ekonomi tambahan bagi masyarakat untuk meningkatkan kesejahteraan masyarakat Desa Dulamayo Selatan.

\section{UCAPAN TERIMAKASIH}

Terimakasih kepada rekan-rekan tim Abdimas UT - Gorontalo dan LPPM UT. Terimakasih atas kerjasama luar biasa dari mitra Abdimas, Ibu dan Bapak aparat, perangkat dan pengurus Bumdes Desa Dulamayo Selatan.

\section{REFERENSI}

Anggraini, V. (2020). Media Sosial :

Pengertian, Jenis, Fungsi dan Tujuan.

Dosen Pintar.

Barokah, S., Wulandari, O. A. D., Sari, M. T., \& Yuditama, I. F. (2021). Optimalisasi Digital Marketing melalui Facebook Ads di Kelurahan Purwanegara. Jurnal
Abdimas BSI: Jurnal Pengabdian Kepada Masyarakat, 4(1).

https://doi.org/10.31294/jabdimas.v4i1.70 85

Dewa, C. B., \& Safitri, L. A. (2021).

Pemanfaatan Media Sosial Tiktok Sebagai

Media Promosi Industri Kuliner Di

Yogyakarta Pada Masa Pandemi Covid-19

(Studi Kasus Akun TikTok Javafoodie).

Khasanah Ilmu - Jurnal Pariwisata Dan

Budaya, 12(1).

https://doi.org/10.31294/khi.v12i1.10132

Fauzan, A. (2019). Penggunaan Media Youtube

Dan Sikap Pengguna Media Youtube.

KINESIK, 6(3).

https://doi.org/10.22487/ejk.v6i3.85

Puspitarini, D. S., \& Nuraeni, R. (2019).

Pemanfaatan Media Sosial Sebagai Media

Promosi. Jurnal Common, 3(1), 71-80.

https://doi.org/10.34010/COMMON.V3I1. 1950

Setiasih, S., \& Puspitasari, F. I. (2017).

Kebutuhan Remaja Untuk Mengirim Foto

Atau Video Di Instagram. Jurnal

Psikologi Ulayat, 2(2).

https://doi.org/10.24854/jpu22015-40

Zeng, B., \& Gerritsen, R. (2014). What do we

know about social media in tourism? A

review. Tourism Management

Perspectives, 10, 27-36.

https://doi.org/10.1016/J.TMP.2014.01.00 1

\section{SUMBER WEBSITE}

https://bappeda.gorontaloprov.go.id/institution/ $\mathrm{read} / 187 /$ diakses 11 September 2021

www.romelteamedia.com/2014/04/media-

sosial-pengertian-karakteristik.html) diakses 11

September 2021

https://wearesocial.com/digital-2020 diakses 11

September 2021

https://wisatagorontalo.com/puncak-dulamayogorontalo/ diakses 11 September 2021

Teknologi Informasi dan Komunikasi 86 